\title{
APLIKASI LAMA PERENDAMAN BENIH DENGAN POC DAN SISTEM TANAM BENIH LANGSUNG TERHADAP PERTUMBUHAN DAN HASIL PADI SAWAH (Oryza sativa L.) KULTIVAR CIHERANG
}

\section{Application of Seeds Soaking Time Using Liquid Organic Fertilizers and Direct Seed Planting Systems on the Growth and Yield of Lowland Rice (Oryza sativa L.) Cultivars of Ciherang}

\author{
Surya Nurhakim Dwi Putra, Jenal Mutakin, *Resti Fajarfika \\ Program Studi Agroteknologi, Fakultas Pertanian, Universitas Garut \\ Jl. Raya Samarang No.52A, Tarogong Kaler, Garut, Jawa Barat 44151 \\ e-mail: fajarfikaresti@gmail.com
}

\begin{abstract}
Abstrak
Pupuk organik cair mengandung unsur hara makro dan mikro, serta mikroorganisme yang bermanfaat untuk tanaman. Penelitian bertujuan untuk mengetahui pengaruh lama perendaman benih dalam pupuk organik cair dan sistem tanam benih langsung yang memberikan pengaruh tertinggi terhadap pertumbuhan dan hasil padi kultivar Ciherang. Penelitian menggunakan Rancangan Acak Kelompok pola faktorial 4 x 3 dengan 3 ulangan. Faktor pertama adalah lama perendaman benih dalam pupuk organik cair (P) dengan 4 taraf (12, 24, 36, dan 48 jam). Faktor kedua yaitu sistem tanam benih langsung (T) terdiri atas 3 taraf $(3,6$, dan 9 benih). Data dianalisis menggunakan Uji F, apabila berbeda nyata dilanjutkan dengan Uji Duncan (DMRT) taraf 5\%. Hasil penelitian menunjukkan tidak terjadi interaksi antara lama perendaman benih dalam pupuk organik cair dan sistem tanam benih langsung terhadap pertumbuhan dan hasil tanaman padi kultivar Ciherang. Secara mandiri, lama perendaman dalam pupuk organik cair 36 jam dan sistem tanam benih langsung tabela 6 berpengaruh paling baik terhadap pertumbuhan dan hasil kultivar Ciherang, yaitu meningkatkan tinggi tanaman, jumlah daun per rumpun, jumlah anakan per rumpun, jumlah malai per rumpun, bobot gabah kering panen per rumpun, hasil gabah kering panen per plot, bobot gabah kering giling per rumpun, dan hasil gabah kering giling per plot.
\end{abstract}

Kata kunci : Ciherang, padi, pupuk, tabela, perendaman

\section{Abstract}

Liqiud organic fertilizer contains the nutrient of macro, micro, and microorganism which have beneficial for plants. The research was aimed to determine the influence of seeds soaking time in liquid organic fertilizer and direct seed planting systems which had the highest effect on the growth and yield of lowland rice Ciherang cultivars. The research design used a Randomized Block Design with factorial pattern consisted of $4 x$ 3 with 2 replications. The first factor was seeds soaking time in liquid organic fertilizers (P) consist of four level $(12,24,36,48$ hours). The second factors was direct seed planting systems $(T)$ consist of three level (3, 6, and 9 seeds). Data were analyzed using 
the F test, if significantly different followed by the Duncan Multiple Range Test (DMRT) level 5\%. The results showed that there was no interaction between the seeds soaking time in liquid organic fertilizer and the direct seed planting system on the growth and yield of the rice cultivar Ciherang. Independently, soaking time in liquid organic fertilizer 36 hours and direct seed planting system Tabela 6 had the best effect on the growth and yield of Ciherang cultivars, namely increasing plant height, number of leaves per clump, number of tillers per clump, number of panicles per clump,weight of dry grain, yield of dry unhulled rice per plot, weight of milled dry grain per hill, and yield of milled dry grain per plot.

Keyword : Ciherang, rice, fertilizer, tabela, soaking

\section{Pendahuluan}

Padi merupakan komoditas strategis yang mempunyai kedudukan sangat penting baik secara ekonomi maupun sosial. Padi sebagai tanaman pangan dikonsumsi kurang lebih 90\% dari keseluruhan penduduk Indonesia untuk makanan pokok sehari-hari dan sebagai sumber karbohidrat serta diusahakan oleh sebagian besar masyarakat tani Indonesia, baik di lahan sawah irigasi, tadah hujan, lahan kering maupun di lahan pasang surut (Saragih, 2001).

Berdasarkan petumbuhan produksi padi dari tahun 2014-2018 secara berturut-turut yaitu 67.102.361 ton, 71.766.496 ton, 75.482.556 ton, 77.366.049, ton, dan 78.819.137 ton dengan rata-rata peningkatan produktivitas yang terus meningkat, yaitu $52.98 \mathrm{ku} / \mathrm{ha}$, $55.08 \mathrm{ku} / \mathrm{ha}, 53.97 \mathrm{ku} / \mathrm{ha}, 53.15 \mathrm{ku} / \mathrm{ha}$, dan $53.54 \mathrm{ku} / \mathrm{ha}$ (Direktorat Jenderal Tanaman Pangan, 2018). Angka produksi padi yang terus meningkat perlu lebih ditingkatkan, atau paling tidak tetap dipertahankan.

Salah satu cara untuk meningkatkan hasil padi dapat menggunakan benih yang berkualitas. Benih adalah tanaman atau bagiannya yang digunakan untuk memperbanyak dan atau mengembangbiakkan tanaman. Benih yang berupa biji memiliki kulit keras, sehingga sulit berkecambah. Sutopo (2005) menyatakan bahwa benih yang memiliki kulit keras biasanya mengalami dormansi dengan tipe dormansi fisik, dengan adanya pembatasan struktural pada perkecambahannya. Dormansi merupakan cara embrio biji mempertahankan diri dari keadaan lingkungan yang tidak menguntungkan, tetapi berakibat lambatnya proses perkecambahan.

Dormansi benih menunjukkan suatu keadaan dimana benih-benih sehat (viable) gagal berkecambah meskipun berada pada kondisi yang cocok untuk perkecambahan. Dormansi dapat disebabkan oleh keadaan fisik dari kulit benih, keadaan fisiologis dari embrio atau kombinasi dari ke dua keadaan tersebut. Namun, dormansi bukan berarti benih tersebut mati atau tidak dapat tumbuh kembali. Perendaman sering dilakukan untuk memecahkan dormansi benih, bertujuan untuk menjadikan agar kulit biji lebih mudah masuk air pada saat imbibisi. Perendaman menggunakan air bersuhu tinggi teruji efektif menghilangkan bahan-bahan penghambat perkecambahan dan memicu pembentukan hormon pertumbuhan sehingga biji dapat berkecambah (Sutopo, 2005). Hasil penelitian Agustina dan Syamsiah (2018) menunjukkaan bahwa lama perendaman benih dengan larutan mikroorganisme lokal selama 16 jam memberikan pengaruh 
paling baik di setiap parameter pengamatan, yaitu terhadap persentase perkecambahan benih, persentase bibit tumbuh normal, rata-rata tinggi tanaman, rata-rata jumlah daun, ratarata panjang akar, rata-rata bobot segar bibit padi.

Selain benih, faktor yang mempengaruhi produktivitas padi sawah adalah cara tanam. Cara tanam padi di Indonesia umumnya menggunakan dua cara yaitu cara tanam pindah atau tapin dan cara tanam benih langsung atau tabela. Tanam pindah banyak dipakai petani di Indonesia dibandingkan tabela dan cara tabela sangat menguntungkan jika ditanam pada lahan sawah irigasi (Putra, 2012).

Di Indonesia, sistem tabela sudah mulai diadopsi oleh petani, terutama di daerah sentra produksi padi dengan tenaga kerja langka dan mahal. Di Sulawesi Selatan, Sumatera Utara, dan Lampung, sistem tabela basah sudah berkembang di kalangan petani karena tenaga kerja yang langka dan mahal. Penaburan benih dalam larikan dapat menggunakan alat yang disebut atabela (alat tanam benih langsung). Di daerah transmigrasi pasang surut Sumatera Selatan, tabur benih rata (broadcast seeding) cukup populer dengan sebutan sistem tanam sonor. Sistem ini, curahan tenaga kerja untuk menanam padi hanya 12 orang/ha. Sistem ini dapat meningkatkan indeks panen karena waktu tanam dan waktu panen bisa lebih awal (Pane, 2003).

Menurut Bambang (2011) dikutip Soraya dan Barus (2015), beberapa keuntungan budidaya padi dengan sistem tabela adalah jarak tanam lebih tepat dan teratur sehingga produksi yang diperoleh petani lebih banyak 500-1000 kg gabah kering per hektar bila dibandingkan dengan sistem persemaian, dengan sistem tabela dapat menghasilkan 66,5 ton gabah kering, sedangkan melalui sistem persemaian konvensional (Tapin) menghasilkan 5-5,5 ton gabah kering, dan karakteristik tanaman padi yang cocok ditanam dengan sistem tabela adalah kultivar Ciherang.

Berdasarkan beberapa hasil penelitian tentang aplikasi lama perendaman benih dan sistem tanam benih langsung dapat menjadi petunjuk awal tentang kemampuan benih untuk tumbuh lebih cepat dibandingkan dengan pertumbuhan padi umumnya. Oleh sebab itu, perlu dilakukan penelitian tentang bagaimana respon benih padi kultivar Ciherang terhadap aplikasi lama perendaman dalam pupuk organik cair dengan jumlah benih yang berbeda pada sistem tanam tabela.

\section{Metodologi}

Bahan yang digunakan adalah benih padi kultivar Ciherang, pupuk organik cair (GDM berbentuk cair dengan kandungan $\mathrm{N}, \mathrm{P}, \mathrm{K}, \mathrm{C}, \mathrm{Ca}, \mathrm{Mg}$, Bacillus brevis, Bacillus pumillus, Bacillus mycoides, Pseudomonasl caligenes, Pseudomonas mallei, Klebsiella oxytoca, Micrococcus roseus). Penelitian menggunakan Rancangan Acak Kelompok (RAK) pola faktorial $4 \times 3$ dengan 3 ulangan, sehingga terdapat 36 plot, setiap plot terdapat 100 rumpun tanaman. Faktor pertama yaitu lama perendaman benih dalam pupuk organik cair selama12, 24, 36, dan 48 jam. Faktor kedua adalah jumlah benih dalam sistem tabela terdiri atas 3, 6, dan 9 benih per lubang tanam. Penelitian dilaksanakan di Desa Sukajaya Kecamatan Cisewu, Kabupaten Garut pada bulan Desember 2019 sampai Maret 2020. Lokasi percobaan terletak pada ketinggian 700 meter di atas permukaan laut. 


\section{Persiapan lahan}

Proses pengolahan tanah dilakukan dengan cara pembajakan, kemudian digenangi selama satu minggu dan diolah kembali. Selanjutnya pembuatan plot dengan ukuran 2,5 $\mathrm{m} \times 2,5 \mathrm{~m}$, jarak plot perlakuan dalam setiap blok ulangan adalah $0,5 \mathrm{~m}$, jarak antara blok ulangan 1 meter. Pencegahan genangan air dengan membuat saluran mengelilingi plot.

\section{Aplikasi Perlakuan}

Benih direndam larutan air garam selama 15 menit dan dibilas sebanyak 3 kali dengan akuades untuk menghilangkan kandungan garam pada permukaan benih. Selanjutnya benih direndam dalam pupuk organik cair sesuai dengan perlakuan lama perendaman pada suhu ruang. Sebanyak $25 \mathrm{ml}$ pupuk organik cair untuk $1 \mathrm{~kg}$ benih.

\section{Penanaman}

Penanaman benih dilakukan sesuai perlakuan jumlah benih dengan jarak tanam $25 \times 25$ $\mathrm{cm}$.

\section{Pamupukan}

Pupuk yang digunakan berdasarkan rekomendasi Dinas Pertanian Kabupaten Garut (2018) adalah Urea $250 \mathrm{~kg} / \mathrm{ha}, \mathrm{SP}-3615 \mathrm{~kg} / \mathrm{ha}$, dan $\mathrm{KCl} 100 \mathrm{~kg} / \mathrm{ha}$ sehingga dosis pupuk untuk setiap plot, yaitu 156,25 g Urea /plot, $93 \mathrm{~g} \mathrm{SP-36/plot,} \mathrm{dan} \mathrm{62,5} \mathrm{g} \mathrm{KCl}$ /plot. Pemupukan dilakukan dengan cara ditabur. Pupuk Urea diaplikasikan sebanyak tiga kali yaitu pemupukan pertama dilakukan sebelum tanam sebanyak 1/3 bagian dosis, pemupukan kedua dan ketiga dilakukan pada saat tanaman berumur 21 dan 42 HST masing-masing sebanyak $1 / 3$ bagian dosis. Pupuk SP-36 dan $\mathrm{KCl}$ diberikan seluruhnya sebelum tanam.

\section{Parameter pengamatan}

Pengamatan meliputi tinggi tanaman, jumlah daun, jumlah anakan, jumlah malai, bobot gabah kering panen, bobot gabah kering giling, dan bobot 1000 butir.

\section{Analisis Pengamatan}

Data dianalisis menggunakan Uji F, apabila berbeda nyata dilanjutkan dengan Uji Jarak Berganda Duncan atau Duncan Multiple Range Test (DMRT) taraf 5\%.

\section{Hasil Dan Pembahasan}

Analisis statistik menunjukkan tidak terjadi interaksi antara lama perendaman benih dan sistem tanam benih langsung terhadap semua parameter pengamatan.

\section{TINGGI TANAMAN}

Hasil analisis lama perendaman benih menggunakan pupuk organik cair (POC) dan sistem tanam benih langsung (tabela) terhadap tinggi tanaman tinggi padi pada Tabel 1. menunjukkan tidak berbeda nyata pada umur 14 dan 21 hari setelah tanam (HST). Hal ini diduga tanaman pada umur tersebut masih menggunakan cadangan makanan dalam 
endosperm dan adanya tambahan unsur hara dari pupuk organik cair dalam larutan yang relatif sama sebagai pelengkap nutrisi (Sastrahidayat, 2011).

Pengamatan umur 28 dan 35 HST pada tinggi tanaman menunjukkan pengaruh perlakuan yang berbeda nyata. Perlakuan optimum menggunakan perendaman benih selama $36 \mathrm{jam}$, hal ini diduga karena pada saat perendaman, kulit benih padi yang kurang impermeable terhadap air dapat dilunakkan, sehingga lebih mudah dimasuki udara dan penyerapan unsur hara yang terdapat pada larutan POC GDM seperti nitrogen, fosfor, kalium, karbon, kalsium, dan magnesium yang dapat memacu perkecambahan yaitu munculnya tumbuhan kecil dari dalam biji. Proses perubahan embrio saat perkecambahan adalah plumula tumbuh dan berkembang menjadi batang (Syamsuri, 2004). Menurut Santoso et al. (2014) bahwa perendaman benih merupakan salah satu metode invigorasi untuk mempercepat tumbuhnya kecambah dan menghasilkan bibit yang baik.

Perlakuan sistem tabela 6 benih per lubang pada Tabel 1. menunjukkan perlakuan optimum terhadap tinggi tanaman. Hal ini karena tanaman dapat bersaing untuk mendapatkan unsur hara. Guritno dan Sitompul (1995) menyatakan bahwa salah satu cara untuk mendapatkan pertumbuhan yang baik adalah dengan mengatur populasi tanaman yang optimum, karena persaingan dalam memperoleh unsur hara, air, dan sinar matahari diantara tanaman menjadi lebih rendah.

Tabel 1. Pengaruh Lama Perendaman Benih Padi dalam POC dan Jumlah Benih terhadap Tinggi Tanaman

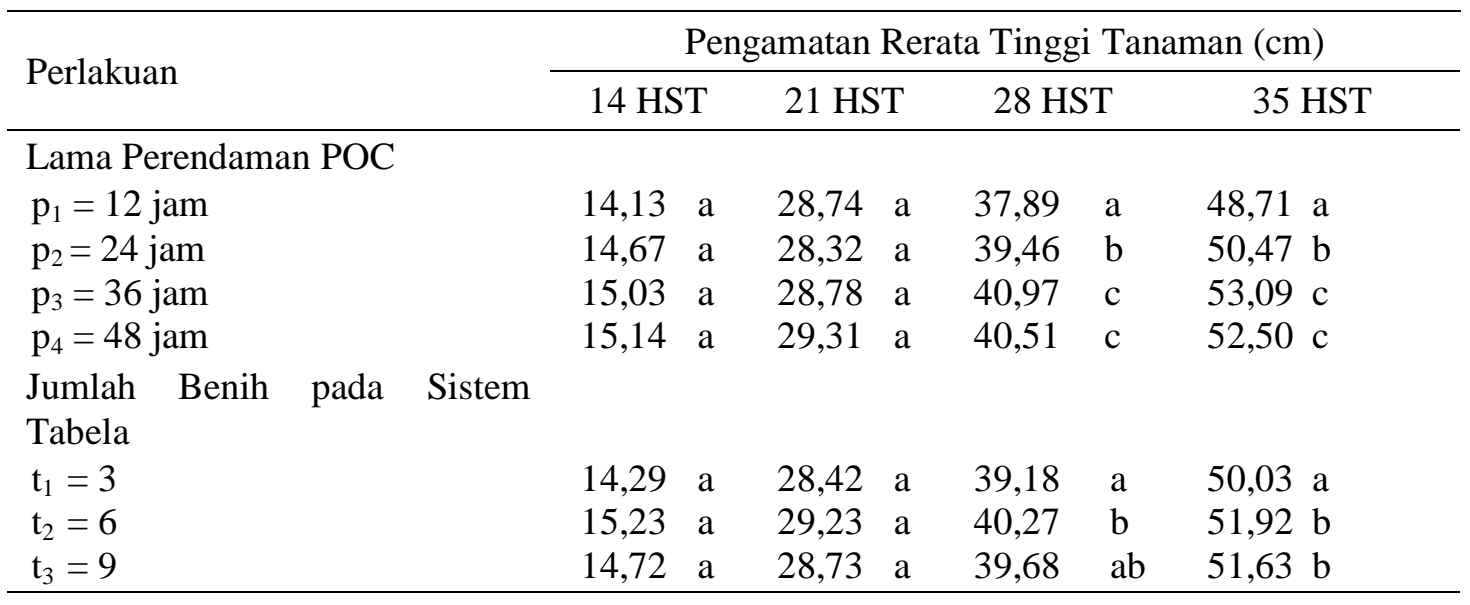

Keterangan: Angka rata-rata yang diikuti huruf yang sama pada setiap kolom, tidak berbeda nyata berdasarkan Uji DMRT pada taraf 5\%.

\section{JUMLAH DAUN PER RUMPUN}

Hasil analisis jumlah daun per rumpun pada Tabel 2. menunjukkan bahwa secara mandiri terdapat perbedaan yang nyata antar perlakuan. Lama perendaman benih padi menggunakan POC selama 36 jam memberikan hasil yang optimal. Hal ini diduga bahwa POC dapat memberikan kebutuhan unsur nitrogen yang dibutuhkan tanaman. Menurut Duaja (2012) bahwa daun berperan sebagai tempat menyintesis makanan dan cadangan makanan untuk kebutuhan tanaman. Unsur hara utama yang mempengaruhi 
pembentukan daun adalah nitrogen, apabila kebutuhan nitrogen tercukupi maka dapat meningkatkan pertumbuhan tanaman.

Lama perendaman selama 36 jam pra perkecambahan menggunakan POC dapat menghasilkan jumlah daun yang banyak. Menurut Rahmatika dan Sari (2020) bahwa benih yang direndam dalam air menyebabkan terbukanya pleugram pada benih, dan memberikan kecepatan pertumbuhan jumlah daun karena air dan oksigen yang dibutuhkan untuk pertumbuhan dapat masuk ke benih tanpa halangan sehingga benih dapat berkembang. Selain itu, perendaman dengan larutan POC memicu bekerjanya enzim hidrolase untuk merombak cadangan makanan yang hasil akhirnya berasal dari primodia daun yang terdapat pada ujung batang. Primodia daun berkembang menjadi daun melalui beberapa tahap hingga terbentuk helaian daun. Seiring dengan pertambahan umur tanaman maka jumlah daun akan semakin meningkat.

Secara mandiri, perlakukan jumlah benih pada sistem tabela menunjukkan pengaruh yang berbeda nyata terhadap jumlah daun per rumpun (Tabel 2). Tabela 6 benih padi per lubang memberikan hasil yang tertinggi. Hal ini diduga bahwa 6 benih per lubang merupakan jumlah yang optimum yang membantu pertumbuhan akar untuk berkembang dan mampu mendapatkan hara dari dalam tanah dan juga air secara optimal, sehingga meningkatkan jumlah daun. Tamin (2007) menjelaskan bahwa kecambah normal umumnya memiliki sistem perakaran yang baik terutama akar primer, perkembangan hipokotil yang baik dan sempurna dengan meningkatnya daun.

\section{JUMLAH ANAKAN PER RUMPUN}

Hasil analilsis jumlah anakan per rumpun pengamatan 21 dan 28 HST secara mandiri berpengaruh nyata terhadap jumlah anakan per rumpun (Tabel 2). Perendaman benih padi selama 36 jam menggunakan POC memberikan hasil yang optimum. Hal ini diduga bahwa mikroorganisme yang terkandung dalam POC mampu meningkatkan daya rangsang dalam mendorong proses penyerapan air pada benih padi yang optimum sehingga pertumbuhan benih padi berlangsung dengan cepat dan mampu memberikan respon fisiologis yang baik terhadap perkembangan tanaman, yaitu meningkatnya jumlah anakan per rumpun. Kemampuan mikroorganisme ini didasarkan atas kemampuan menyediakan dan memobilitasi penyerapan berbagai unsur hara dalam tanah serta menyintesis dan mengubah konsentrasi berbagai fitohormon pemicu pertumbuhan jumlah anakan (Amiroh et al., 2019).

Mikroorganisme yang terdapat pada POC GDM yang digunakan yaitu Bacillus brevis, B. pumillus, dan B. mycoides (golongan bakteri pengurai bahan organik (heterotrof) dan penghasil senyawa antimikroba serta membantu proses penguraian limbah, Pseudomonas alcaligenes, $P$. mallei (golongan bakteri penghasil senyawa antibiotik (antifungal), siderofor, dan metabolit sekunder lainnya yang sifatnya dapat menghambat aktivitas jamur (Haas dan Devago, 2005), Klebsiella oxytoca (bakteri penyedia fosfor), dan Micrococcus roseus berperan dalam memproses unsur-unsur mikro.

Secara mandiri, perlakukan jumlah benih pada sistem tabela pengamatan 21 dan 28 HST menunjukkan pengaruh yang berbeda nyata terhadap jumlah anakan per rumpun (Tabel 2). Jumlah benih per lubang tanam yang optimum yaitu 6 benih per lubang 
tanam, sehingga akan menghasilkan anakan dengan jumlah yang banyak, karena tingkat kompetisi terhadap perebutan cahaya matahari, unsur hara, air, dan juga ruang tumbuh tidak terlalu tinggi.

Tabel 2. Pengaruh Lama Perendaman Benih Padi dalam POC dan Jumlah Benih terhadap Jumlah Daun, Jumlah Anakan, dan Jumlah Malai per Rumpun

\begin{tabular}{|c|c|c|c|c|}
\hline \multirow{3}{*}{ Perlakuan } & \multicolumn{4}{|c|}{ Pengamatan per Rumpun } \\
\hline & \multirow{2}{*}{$\begin{array}{c}\begin{array}{c}\text { Jumlah Daun } \\
\text { (helai) }\end{array} \\
28 \text { HST }\end{array}$} & \multicolumn{2}{|c|}{ Jumlah Anakan } & \multirow{2}{*}{$\begin{array}{c}\text { Jumlah Malai } \\
90 \text { HST }\end{array}$} \\
\hline & & $21 \mathrm{HST}$ & $28 \mathrm{HST}$ & \\
\hline \multicolumn{5}{|c|}{ Lama Perendaman POC } \\
\hline $\mathrm{p}_{1}=12 \mathrm{jam}$ & $67,98 \mathrm{a}$ & $7,33 \mathrm{a}$ & $13,71 \mathrm{a}$ & $13,68 \mathrm{a}$ \\
\hline $\mathrm{p}_{2}=24 \mathrm{jam}$ & $72,07 \mathrm{~b}$ & $7,36 a b$ & $14,70 \mathrm{~b}$ & $13,90 \mathrm{ab}$ \\
\hline $\mathrm{p}_{3}=36 \mathrm{jam}$ & $78,71 \mathrm{c}$ & $8,09 \mathrm{~b}$ & $15,09 \mathrm{bc}$ & $14,89 \mathrm{~b}$ \\
\hline $\mathrm{p}_{4}=48 \mathrm{jam}$ & $75,27 \mathrm{bc}$ & $8,11 \mathrm{~b}$ & $15,73 \mathrm{c}$ & $14,49 \mathrm{ab}$ \\
\hline \multicolumn{5}{|c|}{ Jumlah Benih pada Sistem Tabela } \\
\hline $\mathrm{t}_{1}=3$ & $62,53 \mathrm{a}$ & $6,56 \mathrm{a}$ & $12,49 \mathrm{a}$ & $12,50 \mathrm{a}$ \\
\hline $\mathrm{t}_{2}=6$ & $79,53 \mathrm{~b}$ & $8,46 \mathrm{~b}$ & $16,23 \mathrm{~b}$ & $15,76 \mathrm{c}$ \\
\hline$t_{3}=9$ & $78,46 \mathrm{~b}$ & $8,15 \mathrm{~b}$ & $15,70 \mathrm{~b}$ & $14,46 \mathrm{~b}$ \\
\hline
\end{tabular}

Keterangan: Angka rata-rata yang diikuti huruf yang sama pada setiap kolom, tidak berbeda nyata berdasarkan Uji DMRT pada taraf 5\%.

Menurut Jumin (2012) bahwa kerapatan antar tanaman akan mempengaruhi perkembangan tanaman, dan menurut Husna (2010) bahwa jumlah anakan akan maksimal apabila tanaman memiliki sifat genetik yang baik serta didukung oleh keadaan lingkungan yang menguntungkan yaitu sesuai dengan pertumbuhan dan perkembangan tanaman.

Hasil analisis jumlah malai per rumpun pada Tabel 2. menunjukkan bahwa secara mandiri perlakuan lama perendaman benih padi dengan POC berpengaruh nyata. Perendaman selama 36 jam menunjukkan jumlah malai per rumpun tertinggi. Hasil ini juga sesuai dengan jumlah anakan per rumpun tertinggi terdapat pada perlakuan perendaman benih selama 36 jam, jumlah malai bergantung pada jumlah anakan. Wangiyana et al. (2012) menyatakan bahwa semakin banyak jumlah anakan semakin banyak jumlah malai, dalam arti jumlah anakan per rumpun berkorelasi posistif dengan jumlah malai per rumpun.

\section{JUMLAH MALAI PER RUMPUN}

Pengaruh mandiri perlakukan jumlah benih pada sistem tabela menunjukkan berbeda nyata terhadap jumlah malai per rumpun. Jumlah 6 benih per lubang menunjukkan perlakuan optimal. Hal ini diduga bahwa meningkatnya jumlah malai per rumpun dipengaruhi oleh pertumbuhan vegetatif lainnya seperti jumlah daun dan jumlah anakan yang banyak dapat meningkatkan fotosintesis, fotosintat yang dihasilkan dari proses tersebut akan meningkatkan malai. Menurut Atman (2007) bahwa penanaman bibit dengan jumlah yang relatif lebih banyak menyebabkan terjadinya persaingan sesama tanaman padi (kompetisi inter spesies) yang sangat keras untuk mendapatkan air, unsur hara, $\mathrm{CO}_{2}, \mathrm{O}_{2}$, cahaya dan ruang untuk tumbuh, sehingga pertumbuhan akan menjadi 
tidak normal. Akibatnya, pertumbuhan vegetatif terhambat, sedangkan penggunaan jumlah bibit yang lebih sedikit (1-3 bibit per lubang tanam) menyebabkan persaingan sesama tanaman padi akan lebih ringan, namun jumlah anakan yang terbentuk juga relatif sedikit, demikian juga jumlah malai yang terbentuk cenderung sedikit pula.

\section{BOBOT GABAH KERING PANEN PER RUMPUN, BOBOT GABAH KERING GILING PER RUMPUN, DAN BOBOT GABAH KERING GILING PER PLOT}

Hasil analisis bobot gabah kering panen per rumpun, gabah kering giling per rumpun dan gabah kering giling per plot secara mandiri menunjukkan pengaruh yang berbeda pada perlakuan lama perendaman (Tabel 3). Lama perendaman benih padi menggunakan POC selama 36 jam memberikan hasil optimal terhadap komponen hasil. Hal ini diduga bahwa POC yang digunakan dapat mencukupi kebutuhan unsur hara mendukung pertumbuhan tanaman seperti tinggi tanaman, jumlah daun, jumlah anakan, sehingga berpengaruh terhadap komponen hasil.

Kandungan unsur hara makro dan mikro serta mikroorganisme yang terdapat dalam POC berpengaruh terhadap perkembangan sistem akar yang menyebabkan terjadinya keseimbangan hara yang diserap tanaman, selanjutnya berpengaruh terhadap metabolisme tanaman yang berkaitan dengan peristiwa fotosintesis dan respirasi dalam jaringan tanaman, sehingga dapat meningkatkan hasil gabah. Hal ini sesuai dengan yang dikemukakan Goldsworty dan Fisher (2008) bahwa proses metabolisme dipengaruhi oleh perubahan besar pada lingkungan tanaman yang tercermin dari perubahan pola pertumbuhan dan hasil tanaman, sebagian besar bobot biji padi-padian berasal dari asimilat yang dihasilkan, asimilat yang dihasilkan akan disimpan dalam biji, sehingga bobotnya meningkat. Fitter dan Hay (1998) juga menjelaskan bahwa hasil fotosintesis yang berupa fotosintat digunakan untuk perkembangan tanaman secara keseluruhan, termasuk pembentukan biji.

Secara mandiri, hasil analisis perlakuan jumlah benih pada sistem tabela menunjukkan pengaruh berbeda nyata terhadap bobot gabah kering panen per rumpun, bobot gabah kering giling per rumpun, dan gabah kering giling per plot (Tabel 3). Perlakuan 6 benih per lubang menunjukkan rata-rata komponen hasil tertinggi. Hal ini karena pada perlakuan tersebut memiliki kerapatan yang cukup yang dapat memberikan keleluasaan pada tanaman untuk tumbuh lebih baik, sehingga mempengaruhi bobot biji yang terbentuk. Harjadi (2005) menyatakan bahwa kerapatan tanaman mempengaruhi hasil tanaman, terutama karena keefisienan memanfaatkan faktor tumbuh, umumnya produksi setiap satuan luas tercapai pada populasi yang tinggi karena tercapainya penggunaan faktor tumbuh secara maksimum di awal pertumbuhan, tetapi pada akhirnya penampilan masing-masing tanaman secara individu menurun karena persaingan sehingga tanaman memberikan respon dengan mengurangi ukuran baik pada seluruh tanaman maupun pada bagian-bagian tertentu. Menurut Bozorgi et al. (2011) bahwa tinggi rendahnya produksi padi sangat dipengaruhi juga oleh tingkat kerapatan (density) tanaman, yang sangat tergantung jumlah bibit per lubang.

Selain itu, perlakuan 6 benih per lubang tanam cukup banyak menyediakan ruang bagi tanaman, sirkulasi udara, pemasukan cahaya dan juga aliran air serta penyebaran unsur hara yang lebih merata sehingga memberi pengaruh terhadap hasil tanaman yang lebih 
tinggi. Menurut Dwidjoseputro (2005) bahwa ketersediaan unsur hara diserap tanaman untuk proses sintesa protein dan pembentukkan ATP dan NADP yang digunakan sebagai sumber energi bagi tanaman. Hasil dari proses tersebut yang berupa karbohidrat akan semakin tinggi, yang selanjutnya digunakan untuk pembentukan biji, sehingga bobot gabah kering panen meningkat. Jumlah unsur yang dibutuhkan tanaman berkaitan dengan kebutuhan tanaman untuk tumbuh dengan lebih baik, jika unsur hara tidak tersedia pertumbuhan tanaman terhambat, tetapi apabila jumlah unsur hara mencukupi pertumbuhan tanaman akan optimal (Lakitan, 2008).

Tabel 3. Pengaruh Lama Perendaman Benih Padi dalam POC dan Jumlah Benih terhadap Komponen Hasil

\begin{tabular}{lllll}
\hline Perlakuan & $\begin{array}{l}\text { Bobot gabah } \\
\text { kering panen/ } \\
\text { rumpun }(\mathrm{g})\end{array}$ & $\begin{array}{l}\text { Bobot gabah } \\
\text { kering giling/ } \\
\text { rumpun }(\mathrm{kg})\end{array}$ & $\begin{array}{l}\text { Gabah kering } \\
\text { giling/plot } \\
(\mathrm{kg})\end{array}$ & $\begin{array}{l}\text { Bobot 1000 } \\
\text { butir gabah } \\
(\mathrm{g})\end{array}$ \\
\hline \multicolumn{5}{l}{ Lama Perendaman Benih } \\
$\mathrm{p}_{1}=12 \mathrm{jam}$ & $68,56 \mathrm{a}$ & $40,99 \mathrm{a}$ & $4,15 \mathrm{a}$ & $29,40 \mathrm{a}$ \\
$\mathrm{p}_{2}=24$ jam & $69,51 \mathrm{ab}$ & $41,67 \mathrm{ab}$ & $4,25 \mathrm{ab}$ & $29,48 \mathrm{a}$ \\
$\mathrm{p}_{3}=36 \mathrm{jam}$ & $76,64 \mathrm{c}$ & $43,06 \mathrm{~b}$ & $4,51 \mathrm{c}$ & $30,14 \mathrm{a}$ \\
$\mathrm{p}_{4}=48 \mathrm{jam}$ & $71,64 \mathrm{~b}$ & $42,66 \mathrm{~b}$ & $4,38 \mathrm{bc}$ & $29,68 \mathrm{a}$ \\
$\mathrm{Jumlah}$ Benih pada Sistem Tabela & & & \\
$\mathrm{t}_{1}=3$ & $69,46 \mathrm{a}$ & $41,23 \mathrm{a}$ & $4,21 \mathrm{a}$ & $29,24 \mathrm{a}$ \\
$\mathrm{t}_{2}=6$ & $74,42 \mathrm{~b}$ & $42,97 \mathrm{~b}$ & $4,43 \mathrm{~b}$ & $29,95 \mathrm{a}$ \\
$\mathrm{t}_{3}=9$ & $70,89 \mathrm{a}$ & $42,08 \mathrm{ab}$ & $4,33 \mathrm{ab}$ & $29,83 \mathrm{a}$ \\
\hline
\end{tabular}

Keterangan: Angka rata-rata yang diikuti huruf yang sama pada setiap kolom, tidak berbeda nyata berdasarkan Uji DMRT pada taraf nyata $5 \%$.

Perlakuan jumlah benih per lubang tanam yang lebih rendah ( 3 benih per lubang tanam) tidak akan menyebabkan terjadinya persaingan tanaman terhadap unsur hara, namun tanaman akan memanfaatkan unsur hara sesuai dengan kebutuhannya, sehingga banyaknya unsur hara tidak selalu meningkatkan bobot gabah kering panen dan gabah kering giling yang lebih tinggi di luar potensinya. Hal ini sesuai dengan yang dikemukakan Sutedjo (2005) bahwa tanaman akan memanfaatkan unsur hara sesuai dengan kebutuhannya untuk perkembangannya secara maksimal.

Perlakukan jumlah benih yang lebih tinggi ( 9 benih per lubang tanam) akan menyebabkan terjadinya persaingan dalam penyerapan unsur hara sehingga pertumbuhan dan perkembangan tanaman terhambat. Hal ini sesuai dengan yang dikemukakan Dachban dan Dibisono (2010) bahwa bertambahnya jumlah bibit per titik tanam, cenderung meningkatkan persaingan tanaman, baik antara tanaman dalam satu rumpun maupun antar laju tumbuh tanaman (LTT). Akibatnya, kebugaran tanaman dan tingkat produksi bahan kering per tanaman cenderung menurun, sehingga relatif rendah pula tingkat distribusinya dari daun ke tangkai bunga dan akhirnya sampai ke pembentukan biji.

\section{BOBOT 1000 BUTIR GABAH}


Hasil analisis bobot 1000 butir gabah secara mandiri tidak menunjukkan pengaruh yang berbeda nyata baik pada perlakuan lama perendaman benih dengan pupuk organik cair maupun pada perlakuan jumlah benih dengan sistem tabela (Tabel 3). Hal ini diduga bobot 1000 butir gabah lebih dipengaruhi oleh faktor genetik tanaman. Hal ini sesuai dengan yang dijelaskan Masdar (2005) bahwa bobot biji tidak dipengaruhi oleh jumlah bibit per lubang tanam, tetapi dikarenakan volume lemma dan pallea dari gabah yang ditentukan oleh faktor genetik tanaman itu sendiri, yaitu karakter dan ciri dari tanaman itu sendiri.

\section{Kesimpulan}

Secara mandiri, lama perendaman dalam pupuk organik cair selama 36 jam dan jumlah 6 benih pada sistem tabela mampu meningkatkan tinggi tanaman, jumlah daun per rumpun, jumlah anakan per rumpun, jumlah malai per rumpun, bobot gabah kering panen per rumpun, hasil gabah kering panen per plot, bobot gabah kering giling per rumpun, dan hasil gabah kering giling per plot.

\section{Daftar Pustaka}

Agustina, T. dan M. Syamsiah. 2018. Aplikasi Lama Perendaman Benih dengan MOL (Mikroorganisme lokal) dari Akar Putri Malu dalam Memacu Pertumbuhan Bibit Padi Pandanwangi. Agroscience Vol 8 (1): 1-18.

Amiroh, A., A. U. Nazam, dan Suharso. 2019. Kajian Pengaruh Jumlah Bibit Per Lubang dan Jarak Tanam terhadap Pertumbuhan Dan Produksi Padi (Oryza sativa L.). Jurnal Agroradix, Vol. 3 (1): 9-19.

Atman. 2007. Teknologi Budidaya Padi Sawah Varietas Unggul Baru Batang Piaman. Jurnal Ilmiah Tambuah, Vol. 6 (1): 58-64

Bozorgi, H.R., A. Faraji, R.K. Danesh, A. Keshavarz, E. Azarpour, F. Tarighi. 2011. Effect of Plant Density on Yield and Yield Components of Rice. World Applied Sciences Journal 12 (11): 2053-2057.

Dachban dan Dibisono. 2010. Pengaruh Sistem Tanam, Varietas Jumlah Bibit Terhadap Pertumbuhan dan Hasil Padi Sawah (Oriza sativa L.). Jurnal Ilmiah Pendidikan Tinggi, Vol 3 (1): 47-57.

Direktorat Jenderal Tanaman Pangan. 2018. Luas Panen, Produksi, dan Produktivitas Padi. https://www.pertanian.go.id. Diakses 3 September 2020.

Duaja, M. D. 2012. Pengaruh Bahan dan Dosis Kompos Cair terhadap Pertumbuhan Selada (Lactuca sativa). Bioplantae, Vol.1(1): 10-18.

Dwidjoseputro, D. 2005. Pengantar Fisiologi Tumbuhan. Gramedia, Jakarta.

Fitter A.H. dan R.K.M. Hay. 1998. Fisiologi Lingkungan Tanaman. Gajah Mada University Press, Yogyakarta.

Goldsworthy, P. R. dan N. M. Fisher. 2008. Fisiologi Tanaman Budidaya Tropik. Terjemahan Tohari. Gadjah Mada University Press, Yogyakarta. 
Guritno, B. dan S.M. Sitompul. 1995. Analisis Pertumbuhan Tanaman. Gadjah Mada University Press, Yogyakarta.

Haas, D. dan G. Devago. 2005. Biological Control of Soil Borne Pathogens by Pseudomonas fluorescenst. Nature Reviews Microbiology, Vol.3. 307-319.

Harjadi, S.S. 2005. Pengantar Agronomi. Gramedia Pustaka, Jakarta.

Husna, Y. 2010. Pengaruh Penggunaan Jarak Tanam terhadap Pertumbuhan dan Produksi Padi Sawah (Oryza sativa L.). Varietas Batang Piaman dengan Metode SRI (System of Rice Intensification). Jurnal Agroteknologi Fakultas Pertanian Universitas Riau. Vol. 1 (9): 2-7.

Jumin, H.B. 2012. Agronomi. Raja Grafindo Persada, Jakarta.

Lakitan, B. 2008. Fisiologi Pertumbuhan dan Perkembangan Tanaman. Rajawali Press, Jakarta.

Masdar. 2005. Interaksi Jarak Tanam dan Jumlah Bibit per Titik Tanam pada Sistem Intensifikasi Padi terhadap Pertumbuhan Vegetatif Tanaman. Akta Agrosia. Vol 1 (1): 92-98.

Pane, H. 2003. Kendala dan Peluang Pengembangan Teknologi Padi Tanam Benih Langsung. J. Litbang Pertanian Vol. 22 (4): 172-178.

Putra, I.G.N.A. 2012. Penerapan Sistem Tanam Tabela, SRI, dan Tanam Pindah Terhadap Komponen Hasil Padi Hibrida dan Varietas Unggul Baru. http://digilid.polije.ac.id. Diakses 1 September 2020.

Rahmatika, W. dan A, E. Sari. 2020. Efektivitas Lama Perendaman Larutan KNO3 terhadap Perkecambahan dan Pertumbuhan Awal Bibit Varietas Padi (Oryza sativa L.). Jurnal Agrovigor, 13 (2): 89-93.

Santoso, I., Sulistyani, dan Sudarsianto. 2014. Studi Perkecambahan Benih Kakao Melalui Metode Perendaman. Pusat Penelitian Kopi dan Kakao Indonesia, Jember.

Sastrahidayat, R. 2011. Rekayasa Pupuk Hayati Mioriza dalam Meningkatkan Produksi Pertanian. Universitas Brawijaya Press, Malang.

Saragih, B. 2001. Agribisnis: Paradigma Baru Pembangunan Ekonomi Berbasis Pertanian. Loji Grafika Griya Sarana, Bogor.

Soraya dan J. Barus. 2015. Kajian Sistim Tanam terhadap Pertumbuhan dan Hasil Beberapa Varietas Unggul Baru Padi Sawah Tadah Hujan. Prosiding Seminar Nasional Agroinovasi Spesifik Lokasi Untuk Ketahanan Pangan Pada Era Masyarakat Ekonomi ASEAN. Hal. 349-355.

Sutedjo, M.M. 2005. Pupuk dan Cara Pemupukan. PT. Asdi Mahasatya, Jakarta.

Sutopo, L. 2005. Teknologi Benih. Rajawali Press, Jakarta. 


\section{Halaman 341 -352}

Syamsuri, I. 2004. Biologi. Erlangga, Jakarta.

Tamin, R. P. 2007. Teknik Perkecambahan Benih Jati (Tectona grandis Linn. F.). Jurnal Agronomi, 11(1):7-14.

Wangiyana, W. Z. Laiwan dan Sanisah. 2012. Pertumbuhan dan Hasil Tanaman Padi Var. Ciherang dengan Teknik Budi Daya "SRI (System of Rice Intencivication)" pada Berbagai Umur dan Jumlah Bibit Perluang Tanam. Jurnal Crop Agro, Vol. 2 (1): 70-78. 